\title{
Women in Science and Engineering: A Framework for an Honors Under- graduate Curriculum
}

\section{Dr. Angela M Kelly, Stony Brook University}

Angela M. Kelly is an Associate Professor of Physics and the Associate Director of the Science Education Program at Stony Brook University, New York. She attended La Salle University, Philadelphia, Pennsylvania, where she received her B.A. degree in chemistry, and completed her M.A. and Ph.D. degrees in science education (2000 and 2006, respectively) and her Ed.M. degree in curriculum and teaching (2007) at Teachers College, Columbia University, New York. She is the recipient of the SUNY Chancellor's Award for Excellence in Teaching (2016); the Provost's Faculty Recognition Award for Excellence in Scholarship and Research from Lehman College, City University of New York (2010); and the Outstanding Teaching Award from Teachers College, Columbia University (2006). Her research has been rooted in a commitment to equity in precollege and university science and engineering.

\section{Doreen Aveni, Stony Brook University \\ Dr. Monica Bugallo, Stony Brook University}

Monica Bugallo is a Professor of Electrical and Computer Engineering and Faculty Director of the Women In Science and Engineering (WISE) Honors program at Stony Brook University. She received her B.S., M.S, and $\mathrm{Ph}$. D. degrees in computer science and engineering from University of A Coruna, Spain. She joined the Department of Electrical and Computer Engineering at Stony Brook University in 2002 where she is currently a Professor. Her research interests are in the field of statistical signal processing, with emphasis on the theory of Monte Carlo methods and its application to different disciplines including biomedicine, sensor networks, and finance. In addition, she has focused on STEM education and has initiated several successful programs with the purpose of engaging students at all academic stages in the excitement of engineering and research, with particular focus on underrepresented groups. She has authored and coauthored two book chapters and more than 150 journal papers and refereed conference articles.

Bugallo is a senior member of the IEEE, serves on several of its technical committees and is the current chair of the IEEE Signal Processing Society Education Committee. She has been part of the technical committee and has organized various professional conferences and workshops. She has received several prestigious research and education awards including the award for Best Paper in the IEEE Signal Processing Magazine 2007 as coauthor of a paper entitled "Particle Filtering," the IEEE Outstanding Young Engineer Award (2009), for development and application of computational methods for sequential signal processing, the IEEE Athanasios Papoulis Award (2011), for innovative educational outreach that has inspired high school students and college level women to study engineering, the Stony Brook University Hispanic Heritage Month (HHM) Latino Faculty Recognition Award (2009), and the Chair of Excellence by the Universidad Carlos III de Madrid-Banco de Santander (Spain) (2012). 


\section{Women in Science and Engineering: A Framework for an Honors Undergraduate Curriculum (Work in Progress)}

\section{Introduction}

Recent reform efforts have focused on the disproportionate representation of women in engineering and the physical sciences, since retention rates of women have lagged behind those of male students [1]. This has been attributed to several factors, including poor academic selfefficacy [2], inadequate pre-college preparation [3], [4], and lack of sense of belonging in the field [5]. Gender inequality in science and engineering is a persistent issue and warrants close examination of potential innovations to improve representation $[6,7]$. The Women in Science and Engineering (WISE) Honors program at Stony Brook University has been in existence since 1993, when it was funded by the National Science Foundation to increase the participation of women in science, technology, engineering, and mathematics (STEM). When initial external funding ceased, the University institutionalized the WISE program. WISE Honors is currently housed within the College of Engineering and Applied Sciences (CEAS) and remains a flagship program to promote diversity in STEM at the University [8].

WISE Honors fits the definition of an academic program as defined by Lattuca and Stark: "a planned group of courses and experiences designated for a specific group of students" [9, $p$. 127]. The Program has both planned courses and a set of experiences for high achieving women students pursuing degrees in STEM. No other institution of higher education offers such a

program, with its strong curricular focus in addition to research, service, leadership, and internship. The curriculum consists of a sequenced academic plan that students follow throughout their fouryear undergraduate studies. Both intellectual and professional development aspects are implemented in the curriculum. The Fall 2017 first-year cohort included 100 women distributed by STEM major, as illustrated in Figure 1.

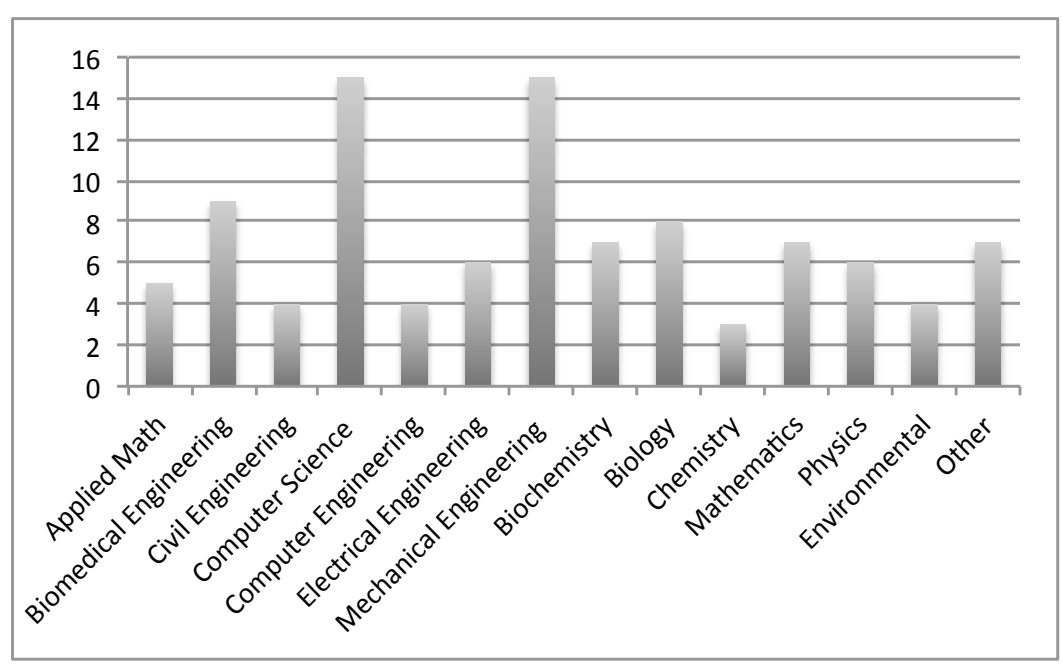

Figure 1. Distribution of WISE freshmen by major, $2017(N=100)$.

\section{Theoretical Foundations}

The WISE Honors curriculum was aligned with two psychosocial theories that support inclusive practices in undergraduate STEM education. The theory of planned behavior suggests that career goal attainment is often strengthened by perceived behavioral control [10]. By providing an honors curriculum that develops academic and professional competence, students may be more likely to persist in their efforts to succeed in engineering and science majors. Secondly, situated learning in communities of practice provides a context for socially constructed learning that 
occurs through sustained collaboration [11]. Young women participating in a network of likeminded individuals have been shown to strengthen agency and STEM identity as they become socialized in their undergraduate majors [12]. CEAS and the WISE Honors Program leveraged these two theories to create a rigorous curriculum for women to achieve excellence in STEM while experiencing a supportive, collaborative learning environment. Additional research has suggested that women's persistence in STEM has been improved by participation in a nurturing community of STEM students, a formal STEM student organization, and undergraduate research [13].

\section{Curriculum Description, Structure and Sequence}

WISE Honors began as a primarily co-curricular program, offering research opportunities, academic advising, mentoring, and professional development activities for undergraduate women. Students in the program followed the requirements of their majors as well as general education requirements of the University. The students reside in a cohabitant learning community during their first year. In addition to participating in enrichment activities, WISE students followed a regular academic plan, plus some additional classes, pertaining to research and gender issues. In 2017, WISE Honors developed a new academic plan - a full 20 credit curriculum - giving the program a new academic focus. All WISE Honors classes were designed to satisfy many of the University's general education courses. Therefore, WISE Honors courses do not burden students with requirements that would not otherwise count for major or general education requirements. The four-year common academic sequence is described below.

First year. The first cohort to enroll in the new curriculum, implemented in Fall 2017, consisted of 100 students (Figure 1). Freshman year focuses on academics. In fall, students take an introductory freshman seminar geared specifically for WISE Honors students to get acclimated to the rigors of college academic work. In spring of the first year, students take a seminar course, Opportunities in STEM and Beyond, which includes guest lecturers to introduce students to the breadth of STEM research and discovery. Learning objectives include understanding the collaborative, interdisciplinary nature of STEM and its worldwide relevance.

Second year. The sophomore year expands on career and research and also emphasizes academics. Society and Gender in STEM explores how gender impacts STEM and uncovers stereotypes and sources of underrepresentation in in the field. Research and Discovery in STEM fosters student capacity to develop a research plan, ethics of research, and communicating findings and implications.

Third year. Junior year brings a focus to service when students enroll in Service-Learning in STEM. The learning objectives of the course include identifying a STEM-related community need and working collaboratively in teams to develop a solution. Year three is when students begin their practical training in STEM, taking four credits selected from two of the following four areas: teaching, mentorship/leadership, research, and internship. These practicum courses develop students' career and research skills.

Fourth year. Senior year promotes leadership. Women's Leadership in STEM focuses on understanding leadership theory, identifying challenges of women in leadership roles, exploring 
pathways to STEM leadership, and developing a personal plan for professional growth. The fourth year also culminates with the honors project or thesis, taken over two semesters. Students develop their own research plans, engineering design projects, or theses, and present their work at the end-of-year symposium. They develop an in-depth understanding of identifying and solving STEM problems and effectively communicating their work to the general public. The WISE curriculum and associated timeline are summarized in Table 1.

Table 1

WISE Curricular Sequence for Undergraduate STEM Majors

\begin{tabular}{|c|c|c|c|c|}
\hline & FALL & SPRING & ANY SEMESTER & FOCUS \\
\hline First Year & $\begin{array}{l}\text { Introduction to University } \\
\text { Seminar } \\
\text { ( } 1 \text { credit })\end{array}$ & $\begin{array}{l}\text { Opportunities in } \\
\text { STEM and Beyond } \\
\text { (1 credit) }\end{array}$ & & Academics \\
\hline $\begin{array}{l}\text { Second } \\
\text { Year }\end{array}$ & $\begin{array}{l}\text { Society and Gender in } \\
\text { STEM ( } 3 \text { credits) }\end{array}$ & $\begin{array}{l}\text { Research and } \\
\text { Discovery in STEM } \\
(3 \text { credits })\end{array}$ & & Academics \\
\hline Third Year & $\begin{array}{l}\text { Service-Learning in STEM } \\
\text { (1 credit) }\end{array}$ & & $\begin{array}{l}\text { WISE Practicum } \\
(4 \text { credits total in }\end{array}$ & Service \\
\hline \multirow[t]{2}{*}{$\begin{array}{l}\text { Fourth } \\
\text { Year }\end{array}$} & $\begin{array}{l}\text { Women's Leadership in } \\
\text { STEM ( } 1 \text { credit })\end{array}$ & \multirow{2}{*}{$\begin{array}{l}\text { WISE Honors } \\
\text { Project/Thesis II } \\
(3 \text { credits })\end{array}$} & \multirow{2}{*}{$\begin{array}{l}\text { teaching, } \\
\text { mentoring/leadership, } \\
\text { research, internship) }\end{array}$} & Leadership \\
\hline & $\begin{array}{l}\text { WISE Honors } \\
\text { Project/Thesis I ( } 3 \text { credits })\end{array}$ & & & $\begin{array}{c}\text { Thesis or Design } \\
\text { Project }\end{array}$ \\
\hline
\end{tabular}

\section{Challenges}

In incorporating the new curriculum, there were some potential logistical challenges, particularly related to the recruitment of faculty to teach the courses. WISE Honors does not have instructional staff, rather, it relies on affiliated faculty members in other departments who are interested in the WISE mission of promoting women in STEM. Arrangements must be made with STEM department chairs to work out the logistics of teaching loads. Challenges in teaching the WISE Honors curriculum are most pronounced in the research course, in which unique research experiences must be identified for 100 students in laboratories across campus. Furthermore, the arrangement of internships depends upon strengthening and expanding the network of regional industries, companies, and health services organizations. This requires considerable work, however, our extensive faculty network and alumni have been supportive in providing resources and opportunities for current WISE students.

\section{Preliminary Findings}

To measure the effectiveness of the new WISE curriculum in meeting its goals, incoming freshmen $(N=58)$ were surveyed at the end of the fall semester in 2017. Baseline data were collected to explore the following research question: How does participation in the WISE curriculum impact students' self-efficacy, career intentions, and socialization in the major? Perceived behavioral control was measured as it related to academic persistence. Survey questions were adapted from the Engineering Student Survey and Students Persisting in Engineering Survey [14]. 
Findings indicated a strong sense of academic and social integration among the freshmen women. The majority (94\%) spent time outside of school with others interested in engineering, science, or mathematics. Most of the women (76\%) had a clear sense of their career plans after graduation, with some reporting an interest in graduate school in their fields (47\%), working in industry $(14 \%)$, graduate school in other fields $(10 \%)$, working in a government laboratory or agency $(3 \%)$ and starting a business $(2 \%)$. This indicated their academic behaviors were oriented towards meeting specific academic goals. In terms of their sense of belonging, the young women reported fairly strong feelings of camaraderie in extracurricular activities, work outside of class, and friendships with others in their disciplines (percentage responses indicated in Table 2). These responses also suggested participation in a community of practice contributed to their social and academic well-being.

Table 2

Freshmen Women's Sense of Belonging

\begin{tabular}{|c|c|c|c|c|c|}
\hline ITEM & $\mathbf{A}$ & $\mathbf{A S}$ & DS & $\mathbf{D}$ & NA \\
\hline $\begin{array}{l}\text { 1. When I participate in science, social science, or engineering professional } \\
\text { societies or extracurricular activities, I feel welcome. }\end{array}$ & 55 & 36 & 9 & 0 & 0 \\
\hline 2. I enjoy working with other students on group work outside of class. & 41 & 47 & 7 & 5 & 0 \\
\hline 3. I have many friends who are studying my discipline. & 50 & 33 & 12 & 3 & 2 \\
\hline
\end{tabular}

Response codes: $\mathrm{A}=$ agree, $\mathrm{AS}=$ agree somewhat, $\mathrm{D}=$ disagree somewhat, $\mathrm{D}=$ disagree, $\mathrm{NA}=$ not applicable

The freshmen women also reported strong feelings of self-efficacy in several domains, displaying overwhelming confidence in completing degrees in their major (Table 3).

Table 3

Freshmen Women's Self-Efficacy

\begin{tabular}{|c|c|c|c|c|}
\hline ITEM & $\begin{array}{l}\text { Not at all } \\
\text { confident }\end{array}$ & $\begin{array}{c}\text { Not } \\
\text { confident }\end{array}$ & $\begin{array}{c}\text { Fairly } \\
\text { confident }\end{array}$ & $\begin{array}{c}\text { Very } \\
\text { confident }\end{array}$ \\
\hline $\begin{array}{l}\text { 1. I am confident I will be enrolled in any major in CEAS or } \\
\text { the College of Arts and Sciences in the next academic } \\
\text { year. }\end{array}$ & 3 & 2 & 28 & 67 \\
\hline $\begin{array}{l}\text { 2. I am confident I will complete any science, social science, } \\
\text { or engineering-related degree. }\end{array}$ & 2 & 2 & 33 & 63 \\
\hline $\begin{array}{l}\text { 3. I am confident I will complete any degree at this } \\
\text { institution. }\end{array}$ & 0 & 2 & 29 & 69 \\
\hline
\end{tabular}

WISE first-year students' self-efficacy was further explored in questions related to perceived future success in specific curricula, intended careers, work-life balance, and social integration. On most measures, responses indicated high levels of self-efficacy, however, some participants seemed to have issues associated with balancing work and social life (Table 4). This finding will inform future initiatives to offer workshops in managing the challenges and tensions associated with work-life balance. 
Table 4

Self-Efficacy Measures Related to Academics, Work-Life Balance, Social Integration

\begin{tabular}{|c|c|c|c|c|c|c|c|}
\hline ITEM & SD & $\mathbf{D}$ & SD & $\mathbf{N}$ & $\mathbf{S A}$ & $\mathbf{A}$ & $\mathbf{S A}$ \\
\hline 1. I can succeed in my major curriculum. & 2 & 2 & 2 & 9 & 11 & 42 & 33 \\
\hline 2. Someone like me can succeed in a career related to my major. & 0 & 0 & 2 & 5 & 9 & 28 & 49 \\
\hline $\begin{array}{l}\text { 3. I can succeed in my major while not having to give up } \\
\text { participation in my outside interests. }\end{array}$ & 9 & 5 & 2 & 4 & 21 & 26 & 29 \\
\hline $\begin{array}{l}\text { 4. I can make friends with people from different backgrounds } \\
\text { and/or values. }\end{array}$ & 0 & 2 & 0 & 2 & 12 & 70 & 7 \\
\hline
\end{tabular}

\section{Conclusions}

The WISE Honors curriculum was designed and implemented to improve the experiences of undergraduate women in STEM, with a particular focus on improving retention and their academic and social satisfaction. WISE Honors addressed learning on two levels, cognitive (knowledge, practices) and affective (sense of belonging, self-efficacy). By providing students with honors level academic coursework, coupled with real world skills development, such as research and design projects, and practical leadership experiences, WISE Honors will position students to become effective agents in science and engineering communities. Future research will explore longitudinal impacts of program participation, and how students might be better prepared to balance the demands of their personal and professional lives.

\section{Acknowledgments}

This material is based upon work supported by the National Science Foundation under Grant No. 1647405. Any opinions, findings, and conclusions or recommendations expressed in this material are those of the authors and do not necessarily reflect the views of the funding partners. 


\section{References}

[1] C. Adelman. Women and Men of the Engineering Path: A Model for Analyses of Undergraduate Careers. Washington, DC: US Government Printing Office, 1998.

[2] R. M. Marra, K. A. Rodgers, D. Shen, and B. Bogue, "Women engineering students and self-efficacy: A multi-institutional study of women engineering student self-efficacy," Journal of Engineering Education, vol. 98, pp. 27-38, 2009.

[3] W. Tyson, "Modeling engineering degree attainment using high school and college physics and calculus coursetaking and achievement," Journal of Engineering Education, vol. 100, pp. 760-777, 2011.

[4] M. Issapour and A. M. Kelly, "How student gender, SAT scores and interest in science relates to their performance in introductory coursework in engineering technology," Integrated STEM Education Conference (ISEC), 2015 IEEE $5^{\text {th }}$ (pp. 221-224), Princeton, NJ.

[5] M. C. Murphy, C. M. Steele, and J. J. Gross, "How situational cues affect women in math, science, and engineering settings," Psychological Science, vol. 18, pp. 879-885, 2007.

[6] A. M. Kelly, "Social cognitive perspective of gender disparities in undergraduate physics," Physical Review Physics Education Research, vol. 12, 020116, 2016. [Online]. Available: https://doi.org/10.1103/PhysRevPhysEducRes.12.020116. [Accessed Mach 5, 2018].

[7] G. Nehmeh and A. M. Kelly, "Women physicists and sociocognitive considerations in career choice and persistence," Journal of Women and Minorities in Science and Engineering, vol. 24, pp. 65-89, 2018.

[8] Women in Science and Engineering Honors Program, 2018. [Online]. Available: http://www.stonybrook.edu/wise/. [Accessed March 7, 2018].

[9] L. Lattuca and J. Stark. Shaping the College Curriculum: Academic Plans in Context (2nd ed). San Francisco, CA: Jossey-Bass, 2009.

[10] I. Ajzen, "Perceived behavioral control, self-efficacy, locus of control, and the theory of planned behavior," Journal of Applied Social Psychology, vol. 32, pp. 665-683, 2002.

[11] J. Lave and E. Wenger. Situated Learning: Legitimate Peripheral Participation. New York: Cambridge University Press, 1991.

[12] M. F. Bugallo and A. M. Kelly, "A pre-college recruitment strategy for electrical and computer engineering study," Integrated STEM Education Conference (ISEC) IEEE 2014 (pp. 1-4), Princeton, NJ.

[13] L. Espinoza, "Pipelines and pathways: Women of color in undergraduate STEM majors and the college experiences that contribute to persistence," Harvard Educational Review, vol. 81, pp. 209-241.

[14] Assessing Women and Men in Engineering (AWE). (2007). Engineering Student Survey and Students Persistence in Engineering Survey. [Online] Available: http://www.AWEonline.org. [Accessed March 7, 2018]. 